\title{
Legenda o svetom Jeronimu u hrvatskoglagoljskom Petrisovu zborniku (1468.)
}

\begin{abstract}
Suvremena hagiotopografska istraživanja potvrđuju da je u Hrvatskoj, osobito u Dalmaciji, bio vrlo razvijen kult svetoga Jeronima. Hrvatski su glagoljaši štovali Jeronima kao autora glagoljice i začetnika hrvatskoga glagoljaštva. U starijoj hrvatskoj književnoj i liturgijskoj tradiciji sačuvane su mnoge i raznovrsne legende o svetom Jeronimu. Ti tekstovi, potvrđeni u više pisama i jezika, pisani glagoljicom i latinicom, sadrže najpoznatije motive Jeronimove hagiografije. U ovom je radu obrađena Jeronimova legenda u glagoljskom Petrisovu zborniku (1468). Glagoljska legenda donosi se u latiničnoj transliteraciji.
\end{abstract}

\section{I.}

Među svecima čiji se kult razvio i štovao u srednjovjekovnoj Hrvatskoj, istaknuto i posebno mjesto pripada svetom Jeronimu. Kršćanski otac Sofronije Euzebije Jeronim (Stridon, oko 331./347. - Betlehem, 420.), prevoditelj latinske Biblije (Vulgata), pisac pustinjačkih hagiografija te mnogih homilija i komentara, pripada najznačajnijim autorima europske književnosti i kulture. ${ }^{1}$ Svetoga Jeronima osobito su štovali hrvatski glagoljaši kao autora glagoljice, osnivača glagoljaške tradicije te prevoditelja Biblije na hrvatski jezik. Prvi pisani dokaz o tome da se glagoljica pripisivala svetom Jeronimu nalazi se u pismu pape Inocenta IV. senjskomu biskupu Filipu iz 1248. Papa u pismu kaže kako mu je biskup pisao da je u Hrvatskoj u upotrebi posebno pismo za koje klerici te zemlje tvrde da potječe od blaženoga Jeronima (in Sclavonia est littera specialis, quam illius terrae clerici se habere a beato Jeronimo asserentes, eam observant in divinis oficiis celebrandis). ${ }^{2}$ Teza o povezanosti Jeronima i glagoljice, a time i isticanje glagoljice kao iskonsko hrvatskoga pisma, duboko se ukorijenila u hrvatskoj predaji i imala je značajan odjek u djelima starijih hrvatskih pisaca i povjesničara. U današnjoj slavistici tzv.

1 O životu i djelu svetoga Jeronima još uvijek je temeljna knjiga KELLY 1975, a od recentnije literature na hrvatskom jeziku usp. BRATULIĆ 1990; MANDAC 1995; BADURINA STIPČEVIĆ - GRUBIŠIĆ 2008.

2 RITIG 1910: 215-224; NAZOR 1998: 122; BOGOVIĆ 1998: 56-57. 
jeronimska teorija tumači se kao namjera glagoljaša da se autoritetom svetoga Jeronima zaštite od stalnih prigovora da zbog staroslavenskoga bogoslužja i upotrebe glagoljice potpuno ne pripadaju Rimskoj crkvi. ${ }^{3}$ Povezanost hrvatskoga glagoljaštva s Jeronimom utjecala je i na raširenost kulta sv. Jeronima u drugim slavenskim zemljama, osobito u Češkoj, gdje je Karlo IV. upravo preko slavenskoga apostolata sv. Jeronima nastojao osigurati mjesto luksemburškoj dinastiji u onodobnoj europskoj političkoj eliti. ${ }^{4}$

Crkvena tradicija po kojoj Jeronim potječe iz Dalmacije vrlo je stara, a stara je i njegova bliska veza s hrvatskom kulturnom tradicijom, po kojoj se smatra zaštitnikom Dalmacije i Hrvatom. ${ }^{5}$ Jezgrovito je to objasnio Radoslav Katičić:

„Po živoj predaji sveti se Jeronim iskazuje kao Dalmatinac. Tako je, čini se, bilo već u starini, a kada je u novo doba Dalmacija dobila drugo lice, nisu ni tada njegovi zemljaci zaboravili svetoga Jeronima. Njegova domovina bila je sada slavenska zemlja i u njezinim se crkvama njegovala uz staru latinsku i nova slavenska pismenost. Na slavenskom se jeziku nisu obavljali samo razni crkveni obredi nego se na njem u mnogim crkvama prinosila čak i sama euharistijska žrtva. Razumljivo je što se sve to povezalo s njegovim imenom. Tako je on, Dalmatinac, postao i Jeronim Hrvatin, u očima kasnijega doba čovjek slavenskog jezika, pa se vjerovalo i da je zapadnoj Crkvi svojim prijevodom podario Sveto pismo na latinskom jeziku, Vulgatu, te isto tako preveo crkvene knjige na svoj materinski jezik i tako u svojoj Dalmaciji položio temelje slavenskom bogoslužju. Dvojezična književnost koja se tamo njegovala na latinskom i na slovinskom jeziku, koji se zvao još i hrvatski, zamišljala se kao da u svojim najautoritativnijim i najsvetijim tekstovima potječe upravo od njega. Sveti Jeronim je tako postao zaštitnik i utjelovljenje hrvatske književnosti. U njegovoj bratovštini i u njezinu gostinjcu vjerski je i sav duhovni život bio zasnovan na njoj i prožet njome. Bio je hrvatski.“"

Suvremena su hagiotopografska istraživanja također potvrdila razvijenost kulta svetoga Jeronima u Hrvatskoj, osobito u Dalmaciji; pronađene su 64 crkve posvećene ovomu svecu od 11./12. stoljeća pa do danas. ${ }^{7}$ O svojoj vezi s Dalmacijom Jeronim je progovorio u autobiografiji u djelu De viris illustribus, napisavši da je rođen u Stridonu, na granici Dalmacije i Panonije (oppido Stridonis quod a Gothis eversum Dalmatiae quondam Pannoniaeque confinium fuit).$^{8}$ Mnogi su povjesničari i pisci, još od Tome Arhiđakona, pa do naših dana, raspravljali i

DAMJANOVIĆ 2002: 55-57.

4 VERKHOLANTSEV 2013: 251-286. O kultu i legendi sv. Jeronima vidi i: Ista 2014.

5 Jeronimov suvremenik i protivnik Paladije u Historia Lausiaca naziva ga „neki Hijeronim iz Dalmacije“ (Hieronymos tis apo Dalmatias), cit. prema KATIČIĆ 1998: 101.

6 KATIČIĆ 1991: 371.

7 Usp. BADURINA 2006.

8 De viris illustribus: 135, PL 23, 175. 
pisali o Jeronimovu rodnom mjestu te su Stridon smještali ne samo u Dalmaciju, nego i u Italiju (Akvileja), Mađarsku, Istru, Međimurje (Štrigova), Sloveniju i na druga mjesta. ${ }^{9}$

Mnogi su hrvatski pisci književno obrađivali lik svetoga Jeronima, tako iz starijega razdoblja Marko Marulić, Gverin Tihić, Petar Zoranić, Franjo Glavinić i Hilarion Gašparoti, kao i naši suvremenici, poput Ivana Bakmaza i Marka Grčića. A Tin Ujević u nadahnutom eseju Jeronimova pisma iz 1930. kritički je reagirao na zanemaren odnos svojih suvremenika prema svečevu djelu:

„On je napokon istočio vrela tamnog Orijenta, svoje kršne i gorde Dalmacije, te Hristove lirske i misionske Judeje. Njegova oštrina raspoloženja, gnjevni mig obrva, bit će značajna za mnoge dalmatinske prvake čak ovamo do Nikole Tommasea i mnogih namrgođenih sadašnjaka. (...) Jeronim u narodnoj masi bijaše odvajkada najpopularniji svetac, te mu je povjerena ambasada ove pokrajine u carstvu nebeskom, ali je žalosno da su njegova djela i rad, proučena od šačice erudita, slabo poznati širom krugu čitalaca. (...) Ne popujem, jer to i ne dolikuje laičkim licima, ali i slobodoumna javnost Evrope i Amerike izučava revno biografije i ideologije svetaca, danas na pragu novih vjerskih i fantastičnih vremena." ${ }^{10}$

II.

O svetom Jeronimu napisane su brojne biografije i legende, još u antici, a i kasnije u srednjem vijeku. Glavni su izvori tim životopisima bila Jeronimova književna djela, u kojima je zabilježio autobiografske podatke, zapise o ondašnjim događajima i ljudima, ali i zapise polemika i razmišljanja. To se u prvom redu odnosi na brojne poslanice, zbirku od 154 pisma (Epistulae), koje je Jeronim, boraveći na raznim stranama svijeta (u Rimu, Betlehemu, pustinjama Sirije), pisao svojim prijateljima, suradnicima, ali i protivnicima. ${ }^{11}$

U starijoj hrvatskoj književnoj tradiciji sačuvane su mnoge i raznovrsne legende o svetom Jeronimu te su potvrđene $u$ više pisama i jezika, na hrvatskom crkvenoslavenskom jeziku, hrvatskom i latinskom jeziku te na glagoljskom i latiničnom pismu. ${ }^{12}$

U sanktoralu glagoljskih brevijara koji sadrže čitanja za rujan, na 30. dan toga mjeseca, na dan svečeve smrti, nalazi se oficij u Jeronimovu čast. Takav se oficij čita u brevijarima iz 14. stoljeća: IV. Vrbničkom brevijaru, Vatikanskom Borg. illir.

\footnotetext{
Usp. BRATULIĆ 1990: XXXI-XLIII.

10 Cit. prema Isti: XLIV-XLV.

11 Od nekad većega broja, danas je sačuvana zbirka od 154 poslanice, od kojih se 125 sigurno pripisuje Jeronimu, a druge su ili njemu upućene ili apokrifne. Usp. hrvatske prijevode poslanica u MARKOVIĆ 1908 i SVETI JERONIM 1990.

12 Usp. BADURINA STIPČEVIĆ 2013b: 17-26.
} 
6, Pašmanskom brevijaru i I. Ljubljanskom Ms 161, potom u brevijarima iz 15. stoljeća: II. Ljubljanskom Ms 163, Humskom, Mavrovu brevijaru, Vatikanskom Vat. Slav. 19, Vatikanskom Borg. illir. 10, Vinodolskom i II. Novljanskom brevijaru, kao i u tiskanim brevijarima: Prvotisku brevijara iz 1491., Baromićevu brevijaru iz 1493. i Brozićevu brevijaru iz 1561. Oficij sadrži tri dijela: himnu $B$ (ož)e iže esi sv(ê)tlostb $k r(a)$ sna ... posvećenu Jeronimu, slijedi njegov životopis te odlomak Jeronimove poslanice Eustohiji. ${ }^{13}$

U glagoljskim spomenicima nalaze se i prijevodi iznimno popularnoga srednjovjekovnoga djela o svetom Jeronimu, tzv. Vita et Transitus sancti Hieronymi, koje sadrži više tekstova: osim života sv. Jeronima, ondje se čitaju i opis svečevih čudesa u Troji, pjesme o sv. Jeronimu i tri poslanice. Tekstovi Transita, prevedeni s latinskih predložaka, sačuvani su u Ivančićevu zborniku (Zagreb, Arhiv Provincijalata franjevaca trećoredaca glagoljaša) s početka 15. stoljeća ${ }^{14}$ te $\mathrm{u}$ odlomku kodeksa iz polovine 15. stoljeća (Zagreb, Arhiv Hrvatske akademije znanosti i umjetnosti, Fragm. glag. 77). ${ }^{15}$ Glagoljsko je pak izdanje Transit svetoga Jerolima, tiskano u Senju 1508., najvjerojatnije napravljeno prema talijanskoj inkunabuli Transito de Sancto Girolamo (Venecija, 1487.). ${ }^{16}$ Danas je sačuvano deset primjeraka senjskoga izdanja Transita, a poznata su i tri pokušaja njegova ponovnoga izdavanja na latinici. ${ }^{17}$ Senjskomu Transitu pridodana je i dvanaesteračka pjesma o sv. Jeronimu, koja počinje riječima: Anjelske kriposti vse nebeskoga hora. ${ }^{18}$ Tri varijante te pjesme, koju mnogi autori pripisuju Marku Maruliću, nalaze se i u latiničnim rukopisima. Maruliću se pripisivala i latinična legenda Život svetoga Jerolima, iz rukopisa datiranoga iz 16. stoljeća (Zagreb, Arhiv Hrvatske akademije znanosti i umjetnosti, sign. I b 127). ${ }^{19}$ Ista je verzija legende potvrđena i u latiničnom kodeksu iz biblioteke Laurenziane u Firenzi. Istraženo je da obje legende proizlaze iz zajedničkoga prototipa, koji je bio slobodna prerada jednoga od brojnih talijanskih Tranzita sv. Jeronima..$^{20}$ Od tih se

13 Glagoljski oficij s Jeronimovim životopisom i poslanicom Eustohiji iz Humskoga brevijara (Zagreb, Nacionalna i sveučilišna knjižnica, sign. R 4067) iz 15. stoljeća izdala sam u latiničnoj transliteraciji u BADURINA STIPČEVIĆ 2013b.

14 Dvije poslanice o Jeronimovim čudesima, Pseudo-Augustinova jeruzalemskom biskupu Ćirilu i Pseudo-Ćirilova hiponskomu biskupu Augustinu izdane su u MILČETIĆ 1890: 39-153; Odlomak pod naslovom Čudo sv. Jeronima sa Silvanom iz poslanice Pseudo-Ćirila objavljen je u hrestomatiji hrvatskih srednjovjekovnih tekstova: ŠTEFANIĆ i sur. 1969: 286-289.

Odlomak je izdan i obrađen u ŠTEFANIĆ 1964: 99-160.

Usp. NAZOR 1969: 171-188.

Isti 1998. Dio legende o Jeronimu i lavu iz senjskoga Transita objavljen je u ŠTEFANIĆ i sur. 1969: 283-285.

IVŠIĆ 1931; NAZOR 1965.

Tekst legende objavljen je u JAGIĆ 1869: 226-236 i BADURINA STIPČEVIĆ 2013b: 119-131. VERDIANI 1973. 
tekstova znatno razlikuje još jedna latinična legenda o sv. Jeronimu, zapisana u rukopisu nastalom na prijelazu 16. i 17. stoljeća, a koji prema jeziku i pravopisu potječe iz Dalmacije. Dok su se neka djela o svetom Jeronimu s većom ili manjom vjerojatnošću pripisivala Marku Maruliću, za dva se latinska prozna teksta ipak zna da ih je napisao ovaj autor. ${ }^{21}$ Vjerujući u Jeronimovo dalmatinsko podrijetlo, Marulić je napisao polemičan spis In eos qui beatum Hieronymum Italum fuisse contendunt, u kojemu je poricao tezu da je Jeronim rođen u Italiji, a u životopisu Vita divi Hieronymi opisao je Jeronimovu osobnost i njegovo književno djelo. ${ }^{22}$

III.

U ovom ću radu posebnu pozornost posvetiti legendi o Jeronimu u neliturgijskom glagoljskom Petrisovu zborniku jer se u dosadašnjim proučavanjima nije istraživala. Petrisov zbornik (Zagreb, Nacionalna i sveučilišna knjižnica, sign. R 4001) iz 1468. jedan je od najopsežnijih hrvatskoglagoljskih zbornika. ${ }^{23}$ Obuhvaća 350 stranica, formata $20 \times 13,5 \mathrm{~cm}$, pisanih kurzivnom glagoljicom na papiru. Nekad je bio dio ostavštine obitelji Petris (Petriš) s otoka Krka, a danas je pohranjen u Nacionalnoj i sveučilišnoj knjižnici u Zagrebu. Sadrži 162 različita teksta, među kojima se nalaze brojne hagiografske legende, apokrifi i vizije.

Jeronimova legenda naslovljena Čtenie s(ve)tago Eronima Hrvatina nalazi se

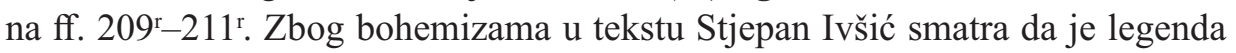
pripadala dijelovima Petrisova zbornika, koji su na hrvatskocrkvenoslavenski prevedeni iz češkoga Pasionala. ${ }^{24} \mathrm{U}$ staročeškoj književnosti Pasionalom se naziva zbirka svetačkih legendi iz 14. stoljeća, koja, osim hagiografija iz Zlatne legende Jacoba de Voragine, sadrži i legende lokalnih svetaca. Jeronimov život u popularnom Voragininu srednjovjekovnom legendariju i češkom Pasionalu opisan je nizom epizoda: navedeno je da je rođen u Stridonu i da je kao mladić otišao na studij u Rim. Istaknuta je Jeronimova privrženost antičkim autorima, koje je radije čitao negoli Sveto pismo. Opisano je kako Jeronim s trideset i devet godina u Rimu postaje kardinal i kako su njegovi protivnici podvalom spriječili da ne postane papa, pa je on povrijeđen i razočaran otišao na Istok, u Konstantinopol kod Grgura Nazijanskog, a odatle u pustinju. Detaljno je prikazan njegov mučan život u pustinji, odakle je otišao u samostan u Betlehem, gdje je ustrajno

\footnotetext{
$\overline{21}$ Usp. TOMASOVIĆ 1999: 89-91.

22 Ovaj životopis pronašao je 1993. Darko Novaković u British Library u Londonu. Usp. NOVAKOVIĆ 1994.

23 Usp. ŠTEFANIĆ 1960: 355-397, o Jeronimovoj legendi na str. 378.

24 IVŠIĆ 1922: 55. Bohemizme je utvrdio u čak sedamnaest tekstova Petrisova zbornika, npr. u legendama o svetom Lovri, sv. Bartolomeju, sv. Mateju, sv. Augustinu, sv. Marku, sv. Blažu i drugima.
} 
prevodio Sveto pismo. Velik dio legende zauzima epizoda o lavu s trnom u nozi, koji dolazi pred Jeronimov samostan. ${ }^{25}$ Legenda na kraju kaže da je Jeronim svoj prijevod Svetoga pisma poslao papi u Rim, da je preminuo u dobi od 98 godina i 6 mjeseci te je pokopan nedaleko od Božjega groba.

Legenda u Petrisovu zborniku sadrži sve redom opisane događaje, ali za razliku od češkoga Pasionala i latinske Zlatne legende, hrvatskoglagoljski tekst ističe Jeronimovo slavensko podrijetlo: u naslovu se Jeronim naziva Hrvatin, a za njegova se oca na početku legende kaže da je slavenskoga podrijetla:

Petrisov zbornik: „S(ve)ti Eronim' imêše o(tb)ca čast'na komu ime bêše Evsebêi slovênskago ezika i slovuĉago egože sin' bê s(ve)ti Eronim'““

Češki pasional: „,waty Jeronym miel otcze wzaczneho gemužto gmeno bylo

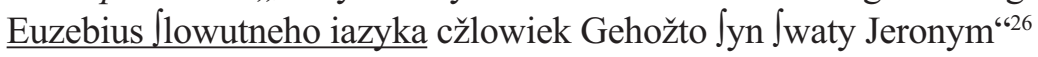

Legenda aurea: „Ieronimus Eusebii viri nobilis filius ab oppido Stridonis quod Dalmatie et Pannonie confinia tenet extitit oriundus".

Podatak o hrvatskom, odnosno slavenskom podrijetlu svetoga Jeronima ne sadrže druge hrvatske legende, ni glagoljske ni latinične; u njima se tek navodi da je Jeronim rođen u Stridonu, na granici Dalmacije i Panonije.

Glagoljska Petrisova legenda sastavljena je od najpoznatijih motiva Jeronimove hagiografije: opisuje Jeronimov san, njegova iskušenja u pustinji te epizodu s lavom. Jeronimov san ili Jeronimova vizija ili visio anticiceroniana prikazuje kako Jeronim u smrtnom strahu obećava vrhovnomu sucu da više neće čitati poganske knjige i više nikada neće biti Ciceronijanac, nego kršćanin. Jeronimova iskušenja u pustinji i ovdje su, kao i u hrvatskoglagoljskim brevijarima, slikovito prikazana odlomkom iz poslanice Eustohiji (Ep. 22, 7). Jeronim je bliskoj prijateljici Pauli, rimskoj udovici koja ga je pratila u Betlehem, i njezinim kćerima, Blesili i Eustohiji, posvetio mnoga pisma, a u ovoj poslanici poučava mladu djevojku Eustohiju i pritom vrlo iskreno progovara o svojim osjećajima. Bez ustručavanja opisuje svoje teškoće u pustinjskoj zabiti, pripovijeda kako je usred pustinje zamišljao rimske zabave, kako se izgladnjivao i osudio na društvo škorpiona i zvijeri. Ova autobiografski intonirana poslanica bolje nego ijedan drugi hagiografski izvor nadopunjuje i ilustrira Jeronimov pustinjački život te stoga ne začuđuje što je našla mjesto i u Jeronimovim srednjovjekovnim legendama.

Poznata je i u likovnim umjetnostima često obrađivana priča o lavu s trnom u nozi, koji dolazi u samostan. Redovnici su se u strahu razbježali, a sveti je Jeronim

\footnotetext{
DA VARAZZE 1998: 1002-1009.

26 JACOBUS DE VORAGINE 1495. Citirani je Pasional inkunabula iz 1495., a prema Ivšićevim istraživanjima, isti je tekst sačuvan u trima rukopisima iz 14. i u dvjema inkunabulama iz 15. stoljeća (usp. IVŠIĆ 1922: 42-43). O Jeronimu u Pasionalu usp. i VERKHOLANTSEV 2013: 277; Ista 2014: 74, 104, 108-109. Zahvaljujem kolegici dr. Petri Stankovskoj na pomoći u prijepisu češkoga teksta.
} 
hrabro dočekao lava, koji mu je pokazao bolesnu šapu. Nakon izlječenja lav ostaje kod fratara, postaje pitoma životinja i magarčev čuvar. Kad se jednom s paše lav vratio bez magarca, optužili su ga da je pojeo magarca i dali mu da radi njegov posao, što je on strpljivo obavljao. No, lav je uspio pronaći magarca, kojega su ukrali trgovci s karavanom deva. Vratio ga je u samostan i tako dokazao svoju nevinost, a s njime su došli i trgovci, moleći Jeronima za oprost. Motiv lava s trnom u šapi vrlo je arhaičan, nalazi se već u Ezopovim basnama, a u Jeronimov je životopis ušao vjerojatno iz hagiografije o svetom Gerasimu, palestinskom monahu iz 4. stoljeća, čije je ime vrlo slično kasnolatinskomu Geronimus. ${ }^{27}$ Priča o lavu potvrđena je već u najstarijim Jeronimovim životopisima, kao što je npr. Vita adscripta Sebastiano mon. Casinensi (incipit: Plerosque nimirum...; BHL 3870, 3872) iz 9. stoljeća. Kasnije je postala dijelom Jeronimovih srednjovjekovnih legendi, pa tako i Zlatne legende. U stručnoj literaturi čudesno izlječenje lava interpretira se i kao alegorija na svečevo duhovno napredovanje jer je Jeronim u toj priči idealiziran kao dobroćudan i gostoljubiv fratar, a taj se prikaz uvelike razlikuje od oštra Jeronimova karaktera, kakav se očituje u njegovim poslanicama i polemičkim spisima. ${ }^{28}$

U hrvatskoglagoljskoj legendi u Petrisovu zborniku sveti Jeronim „Hrvatin“ prikazan je kao marljiv prevoditelj Biblije i kao isposnik koji prolazi kroz tešku pokoru u pustinju, a najveći dio legende zauzima srednjovjekovna popularna priča o Jeronimu i ranjenom lavu. Mnogobrojne i raznovrsne hrvatske srednjovjekovne legende o svetom Jeronimu svjedoče o raširenosti i popularnosti njegova kulta, ali i potvrđuju posebno mjesto koje je ovaj svetac, smatran autorom i zaštitnikom glagoljice i glagoljaštva, imao u hrvatskoj kulturi.

\footnotetext{
27 S. v. JÉRÔME (30 septembre), U Iconographie de l'art chrétien: 741; RICE 1985: 44-45. 28 RICE 1985: 39-45.
} 


\section{$I V$.}

U nastavku donosim još neobjavljen glagoljski tekst legende o svetom Jeronimu iz Petrisova zbornika u latiničnoj transliteraciji.

\section{Hrvatskoglagoljski tekst Legende o svetom Jeronimu \\ Petrisov zbornik, ff. $208^{\mathrm{v}}-211^{\mathrm{v}}$ \\ Čtenie s(ve)tago Eronima Hrvatina ${ }^{29}$}

${ }^{208 v / 23} \mathrm{~S}$ (ve)ti Eronim' imêše o(tь)ca čast'na komu ime bêše Evsebêi slovênskago ezika i slovuĉago egože sin' bê s(ve)ti Eronim' · Oĉe mladı dêtiĉak' ot ove oblasti v Rim' bêža · I tu se nauči knige // ${ }^{209}$ 'grč'ke i latin'ske i židov'ske hitrim' zakonom' čas'ti · I kada v togo sveta umeniju t(e)r se v pogan'skih' knigah' ${ }^{30}$ učaše nego v svêtom' pismê i veĉe se v nem' utêšavaše kada e čtêše $\cdot$ I prigoda se da edno od srditosti udri na nega grozna studêna nemoĉ' · I tako negovu naturu pogasi da $\mathrm{V}$ samêh' nega prseh' nekoliko malo naturne gorkos'ti ostalo bê · I kada se tre vsi od nega života raspačevahu se $\cdot$ I k nega shraneniju potrebnaê pripravlamo $\cdot$ tada v magnovêni oka kako se vidêše vzet' bê na nebo i prnesen' koga kada vsemoĉi sudac' uprosi i r(e)če · Koga staniê esi ti · s(ve)ti Eronim' r(e)če krstênin' ê esam' · tada k nemu sudac' r(e)če lažeš' · nesi krstênin' da esi naslêdnikb pogan'skih' meštrov' i v nih' pis'mê se naslajueš' zač' kadê es(i) skroviĉe tvoe i dragost'. Misli tvoee tu es(u) i srce tvoe · A tada k nemu s(ve)ti Eronim' kako zakrivae se i niĉe mu ne odgovori · I zapovêda ga sudac' nemilostivo biti · I va t' čas' poče s(ve)ti Eronim' vapiti rêkući pom(i)lui me g(ospod)i b(ož)e pom(i)lui me · A natom' ti prisežu da se veĉe ne hoĉu pogan'skih' meštrov' pisma pridržati i v têh' bêsedah' tako prisegaše ' I tude ga prosta pustiše · I tude stoga vidêniê probrav' se naidê se kako da bi znova učinen' i ožil'· I bêše vas' slzami pokroplen' i imêše izbiene rane na svoem' tele kimi bêše bien' ot sudca nemil(o)stivo i vse te rane bêhu nove $\mathrm{i}$ i isčrnele $\cdot$ I ot togo dne poče se veĉe v svetom' $/ /{ }^{209 v}$ pisme s hitrosti i učiti a pogansko ostavi · I k(a)da jure bê $\cdot \hat{\jmath} \cdot(=30) \operatorname{tr} \cdot z \cdot(=9)$ lêt' starb v rimskoi crêkvi v zborê učinen' · Da sveti Eronim' to v svoem' s(ve)tom' običaju imêše da dêonstvo i vse d(u)hovne ot nepodobnago karaše $\cdot$ I zato ti ki se protivlahu nemu

$29 \quad$ Glagoljski tekst objavljuje se u latiničnoj transliteraciji prema načinu uobičajenom u objavlji-

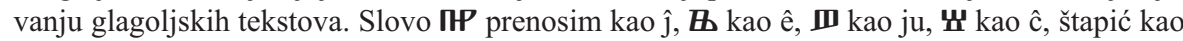
ь i apostrof kao '. Skraćene riječi razriješene su oblim zagradama. Interpunkcijski znakovi i velika slova slijede glagoljski original, a dodatno su vlastita imena napisana velikim slovom. U istraživanju sam se koristila fotografijama Petrisova zbornika iz fototeke knjižnice Staroslavenskoga instituta i digitalizirane kopije Petrisova zbornika, dostupne na Internetu. Izvori Staroslavenskoga instituta: Petrisov zbornik, 1468. (NSK, R 4001). https://izvori.stin.hr/index. php?menu=10 (posjet 1. 4. 2014). 
i vsemi zakoni sramotê iskahu nemu to s(ve)ti vidêv' i poustupi im' $\mathrm{k}$ s'vetomu o(tb)cu Grêgorii Nazaratskomu pridê ki tada biskup' bêše v tom' gradu ki se imenue Kon'stan'tinapol' $i$ ot nega se s(ve)tomu pis'mu skoro nauči ototudb v pustinu ide . O koliko e v toi pustini skozê dragoga Is(u)h(rst)a teš' ki žitak' viduế' trpêl'· I sam' ot sebê dê kada va toi prêgroz'noi pustini bêh' kako da bih' v rimskoi raškoši(!) prêbival' lapêše na moem' têlê vrêtiĉe črno a koža se na moem' životê sčrnêv'ši prisahla bêše $\mathrm{v}$ saražin'sku barvu shrdav'ši obratila se bêše $\cdot$ I takoe pri kostêhь edva lapêše i na vsaki dan' v slzah' ot srca vzdihah' · I kada mê san' utraplaše na z(e)mli svoe kosti i vsem' trudom' premožene êko tako položeĉi otpočineh' · A piĉu i pitiju m(o)l(e)ciim' da kako koli va velikom' želeniju nemoĉan sam' studêne vodê se napiêti · i te sam' ê oĉe na čas' ne imêl' a varênu piĉu jês'ti to sam' za vêlik' greh' držal' · I tako različnim' zvêrom' upodobih' se i škorpiêm' i š nimi tovariš' ki prêbivah' · I kada tako prebih' 'g · $(=4)$ leta v pokaêniju se trudih'· I ottudu vstav' // 210 ridoh' va Vitlêom' · tu v svetom' pis'mê postê se ibo se mole umileno prebivah' $\mathrm{I}$ tu $\mathrm{k}$ nemu mnozi učenici pridoše $\cdot \mathrm{I} \mathrm{s}(\mathrm{ve})$ to žit(i)e poli nega udržahu i tu s(ve)ti Eronim' v s(ve)tom' raz'mislu i v prikladan'i i v stlmačen'i s(veta)go pisma mnogo let' trudi se i v tom' nastoên'i tako se moĉ'no utrudi · Da kada na svoei postêli lêžaše vstati ne moraše takmo primoĉi se uža ko nad nim' visêše · i tako sam' sebê vstati pomogaše ·

I kada ednokrat' s(ve)ti Eronim' sa svoju brat'ju d(u)hovno poslušaše sêdêci a ini s(ve)to pismo čteše $\cdot$ I v tu uru edan' lav' vele velik' hramajuĉi pridê koga oni fratri vidêv'še i veliko se ustrašiše i ki kamo morê ta tamo pobêže $\cdot \mathrm{s}(\mathrm{ve}) \mathrm{ti}$ Eronim' kako proti znanu gostu ništr ne boeĉ' se proti lavu izvidê · I tu lav' kako pitomo zvêrê bolêznivu nogu nemu pokaza kako da bi od nega isceleniê prosil' - Tada s(ve)ti Eronim' prizva brat'ju k sebê - I zapovêda im' lavu nogu umiti i bolêz'ni nega ogledati · I kada učiniše naidoše da nega noga trnom' velikim' moĉno ranena bêše $\cdot$ I tako ob nem' priglêdav'še da mu nogu is'celiše ga I zato ta lav' kako ka ina pitoma tvarb ' tê bêžati ne hotê da tu osta i poče š nimi prebivati · I to vidê s(ve)ti Eronim' da ta lav' ne tuliko za svoe noge bolêzan' k nim' pridê da na posluženie im' b(ogo)m' poslan' bêše · I s brat'skim' svêtom' lavu tu urêdbu naporučiše da bi s kloš'trskim' oslom' ki brat'i izloze drva nošaše da bi bil' š nim' hodil' · i ono ga // ${ }^{210 v}$ posla da bi na paši obaroval' i toe tako bilo · Tada ta lav' poče toga osla pas'ti i varova〈t〉i ga I kada bêše vrêmê v kloštr ga gnaše · I kada edno(m) lav' toga osla pasêše tada edni kupci* todê iduĉi v ta čas' tada lav' bêše usnul' i ti kupci kada nikogdarb ne vidêše ukradoše toga osla i tê ga otvêdoše · I potom' toga kada se lav' zbudi ot sna i ne naidê osla i poče rovuĉi iskati osla semo i tamo têkuĉi - I kada ne more ga naiti i pritêk' prêd' kloštrı ne s'mê sramom' vnutrb $\mathrm{v}$ rêdb poiti kako e onda šal' tr' idê kasne nerê on' da zač sê e prêz' osla vratil'· I tada brati oglêdaše i mnehu da bi bil' gladom' prinuen'

${ }^{*}$ kupci $=$ trgovci 
i da bi bil' osla izel' I zato lavu nega obroka ne daše · i tako mu govorahu osramot'no zvêrê idi · tamo tê i ča si donei · zêl' to šadb doizêi da svoe lakomo črêvo donapl'niš' · I to rêkše mêiju sobu i nadu vêrujuće š nim' na pašu* idoše · ako bi ko znamênie od osla našli i ne naidoše ništr' i vratiše se v kloštr' I s(ve)tomu Eronimu to povêdaše · a on' im' zapovêda da bi lavu oslovu urêdbu učinili · I tako oni narubav'še drv' brême veliko i na lava položiše i rêkoše mu ponesti v kloštr i to lav' vse pokorno trpêše i niĉe ne protivêĉ' se $\cdot$ I kada edno brêmê donese $\cdot i$ poče semo i tamo têkati osla iĉuĉi $\cdot$ I tada se prigodi da ti kup'ci prêks te pustine s vêl'bluda greduĉ' toga osla prêd sobu rênuĉi zač' e takov' zakon' da ka tršci v trštvo gredu s vel'bludi vsagda prêd nimi osla rênu · Zač' // ${ }^{211}$ velbludi neradi ravno gredu · Da kada prêd sobu osla vidê grêduĉa tada po nem' ravno grêdu · I kada lav' poz'na osla svoego riknu vele moĉno i poče repom' v z(e)mlju biti trse ga vêlbludi ustrašivše moraše poiti kamo bê lavu drago i sa svoimi bremêni - A to fratri zaglêdav'še i povêdaše s(ve)tomu Eronimu · a svêti Eronim' r(e)če brat'i draga brat'ê svoim' ustom' noge umite i al'mužno nim' daitê a natom'

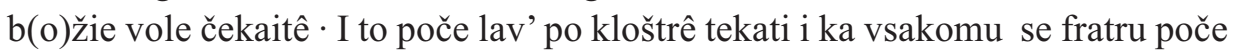
radovati kako znamênie davae da ča e bil' zgubil' to e jure opet' našal'· i kako bl(agoslovle)niê prose da bi šal' s mirom' od nih' i bl(agoslovle)nie priêm' ot' s(ve)toga Eronima i da vse brat'e i otidê ot nih'. I r(e)če s(ve)ti Eronim' bratii. idêtê brat'ê têm' gostom' ki to skoro budut' potrêbu im' pripravitê · ne utegnu toga izreĉi s(ve)ti Eronim' da edan' posal' pridê i povêda s(ve)tomu Eronimu - i r(e)če da bi edni ljudi radi š nim' govorili · I tada kada on' k nim' izidê vsi prêd nim' padoše n(a) z(e)mlju da bi im' krivinu prostil' · I vele poklon'no toga prošahu · I r(e)če s(ve)ti Eronim' vazmitê svoe t'ê a tuega ne haitê** $\cdot$ tada oni počeše prositi s(ve)toga Eronima da bi hotêl' polovicu ul'ê nih' k svoei potrêbê prieti · A ti kup'ci toe mêru ul'ê ob'ljubiše na vsako lêto davati im' · i svoim' mlaišim' po sebê davati zapovêdaše ·

I v ta vrêmêna kako se i to $\mathrm{v}$ staroi ištorii piše božiê služba oĉe po crêkvah' ne bêše podob'no učinena da poêhu i čtêhu // ${ }^{2 l l v}$ vsaki kako e ki mogal' i umêl'. Tada Têodosii c(êsa)rı pape Damasa poprosi da bi nikomu učenomu spravlenie crkvênoga pêt'ê napraviti poručil' - I tako ga sade za podobnu prošnu papa s gotovim' zakonom' usliša · I vidêci s(veta)go Eronima muža svršena va umêni · i v mudrosti i nemu ta trudı poruči i tako bê kako e b(og)b hotêl' · Tada se s(ve)ti Eronim' va t' trudı utêzav' i naprvo psaltêrı koga e na jutrnah' pêti napravi i konci vsakoga psal'ma govoriti sl(a)va o(tb)cu i sinu i d(u)hu s(ve)tu · I tako vsêm' govoriti postavi · I potom' napravi ep(isto)lie i e(van)ĵ(el)ê i različnih' urêdabь spravlênie hotê kotêro kadê kako budê lêto do lêta ta čis'ti napraviv' tre iz' Vitlêoma

\footnotetext{
${ }^{*} \mathrm{U}$ izvorniku: pavu.

** U izvorniku: kaitê.
} 
pape v Rim' posal i vsêm' gardinalom' · to e vse potvreno i do današnago dne · I potom' skon'čav' v starosti lêta svoê i bê živ' na sem' svêtê plnih' ·p· (=90 ) i ·z· $(=8)$ let' i $\cdot e \cdot(=6)$ mêseci skladae mnogie knige i poda se s(ve)tim' · i svršiv' žitie svoe prêda d(u)h' svoi g(ospodo)vê rêki v r(u)ci tvoi g(ospod)i prêdaju d(u)h' moi - I bê blizu b(o)žiju grobu shranen' o h(rbst)ê i(su)se g(ospod)ê na(š)em’ komu es(t) slava i čast' i država va vêki vêk' · Amen'.

\section{Bibliografija}

BADURINA, Anđelko. 2006. Hagiotopografija Hrvatske. Zagreb: Institut za povijest umjetnosti, Kršćanska sadašnjost (CD izdanje).

BADURINA STIPČEVIĆ, Vesna (prir.). 2013a. Hrvatska srednjovjekovna proza I. Legende i romani. Zagreb: Matica hrvatska.

BADURINA STIPČEVIĆ, Vesna. 2013b. Legenda o Jeronimu u starijoj hrvatskoj književnoj tradiciji. U Hagiographia Slavica, ur. Johannes Reinhart, 17-26 [Wiener slavistisches Almanach, 82. Sonderband]. München-Berlin-Wien: Verlag Otto Sagner.

BADURINA-STIPČEVIĆ, Vesna, Vinko GRUBIŠIĆ. 2008. Jeronimove hagiografije. Zagreb: Kršćanska sadašnjost.

Bibliotheca Hagiographica Latina antiquae et mediae aetatis. 1898-1899. Bruxellis: Socii Bollandiani.

BOGOVIĆ, Mile. 1998. Hrvatsko glagoljsko tisućljeće. Senjski zbornik 25: 1-140.

BRATULIĆ, Josip. 1989. Sveti Jeronim i njegove poslanice. Adrias 3: 45-79.

BRATULIĆ, Josip. 1990. Sveti Jeronim Dalmatinac. U Sveti Jeronim, Izabrane poslanice, prir. Josip Bratulić, IX-XLVI. Split: Književni krug.

BRATULIĆ, Josip. 2000. Služba svetom Jeronimu. Colloquia Maruliana 9: 293-304.

DAMJANOVIĆ, Stjepan. 2002. Slovo iskona. Staroslavenska/starohrvatska čitanka. Zagreb: Matica hrvatska.

DA VARAZZE, Jacopo. 1998. De sancto Ieronimo. In Legenda Aurea, ed. critica a cura di Giovanni Paolo Maggioni, 1002-1009. Firenze: Sismel, Edizioni del Galluzzo.

Iconographie de l'art chrétien III. 1915. Ed. Louis Réau. Paris: Presses Universitaires de France.

IVŠIĆ, Stjepan. 1922. Dosad nepoznati hrvatski glagolski prijevodi iz staročeškoga jezika. Slavia 1: 38-56.

IVŠIĆ, Stjepan. 1931. Hrvatska glagoljska dvanaesteračka legenda o sv. Jeronimu, štampana 1508. Nastavni vjesnik 39 [1930-1931]: 1-10.

JACOBUS DE VORAGINE. 1495. Legenda aurea sanctorum (Pasional čili Knihy o životech svatých). Praha: Národní knhovna České republiky, sign. 42.D.36 http://www.manuscriptorium.com/apps/main/en/index.php?request=show_tei digidoc\&virtnum $=15 \& \mathrm{client}=\& d d \_$listpage_pag=204r (posjet 1. 4. 2014).

JAGIĆ, Vatroslav. 1869. Ogledi stare hrvatske proze. III. Život svetoga Jerolima. Starine JAZU 1: 226-236. 
KATIČIĆ, Radoslav. 1991. Ustanove sv. Jeronima u Rimu i povijest hrvatske kulture i narodnosti. U Homo imago et amicus Dei. Čovjek slika i prijatelj božji. Zbornik u čast Ivana Goluba, prir. Ratko Perić, 370-385. Rim: Papinski Hrvatski zavod svetog Jeronima.

KATIČIĆ, Radoslav. 1998. Litterarum studia. Književnost i naobrazba ranoga hrvatskog srednjovjekovlja. Zagreb: Matica hrvatska.

KELLY, John Norman Davidson. 1975. Jerome - His Life, Writings and Controversies. London: Duckworth.

MANDAC, Marijan. 1995. Sveti Jeronim Dalmatinac. Makarska: Služba Božja.

MARKOVIĆ, Ivan. 1908. Izabrane poslanice sv. Jeronima, sv. I-II. Zagreb: Naklada i tisak Hrvatskog katoličkog tiskovnog društva.

MARKOVIĆ, Ivan. ${ }^{2} 1990$, v. BRATULIĆ 1990.

MIGNE, Jacques Paul. 1844-1864. Patrologiae cursus completus. Series Latina. Vol. 1-221. Paris.

MILČETIĆ, Ivan. 1890. Prilozi za literaturu hrvatskih glagoljskih spomenika. Starine JAZU 23: 39-153.

NAZOR, Anica. 1965. Dvanaesteračka legenda o svetom Jeronimu. Slovo 15-16: 214224.

NAZOR, Anica. 1969. Senjski Transit svetoga Jerolima i njegov predložak. Slovo 1819: 171-188.

NAZOR, Anica. 1998. Neki pokušaji ponovnoga izdanja senjskoga Transita sv. Jerolima. U Senjski glagoljaški krug 1248-1508, ur. Milan Moguš, 121-127. Zagreb: Hrvatska akademija znanosti i umjetnosti.

NOVAKOVIĆ, Darko. 1994. Novi Marulić: Vita diui Hieronymi (British Library Ms. Add. 18.029). Colloquia Maruliana 3: 5-24.

PACNEROVÁ, Ludmila. 2008. Staročeské literární památky a charvátská hranatá hlaholice. Slovo 56-57: 405-420.

Petrisov zbornik, 1468. (NSK, R 4001). Izvori Staroslavenskog instituta [Marica Čunčić (ur.), Antonio Magdić (web aplikacija), Ljiljana Mokrović (usklađivanje i unos podataka)]. https://izvori.stin.hr/index.php?menu=10 (posjet 1. 4. 2014).

RICE, Eugen F. 1985. Saint Jerome in the Renaissance. Baltimore-London: Johns Hopkins University Press.

RITIG, Svetozar. 1910. Povijest i pravo slovenštine u crkvenom bogoslužju, sa osobitim obzirom na Hrvatsku. I. sveska od 863-1248. Zagreb: Tiskara i litografija C. Albrecht.

RUNJE, Petar. 1998. O knjigama hrvatskih glagoljaša. Zagreb: Kršćanska sadašnjost, Provincijalat franjevaca trećoredaca.

SALTER, David. 2001. Holy and Noble Beasts: Encounters With Animals in Medieval Literature. Rochester-NY: D. S. Brewer.

SVETI JERONIM. 1990. Izabrane poslanice. Prir. Josip Bratulić. Split: Književni krug. ŠTEFANIĆ, Vjekoslav. 1960. Glagoljski rukopisi otoka Krka [Djela JAZU 51]. Zagreb: JAZU. 
ŠTEFANIĆ, Vjekoslav. 1964. Senjski Transit svetoga Jerolima i njegov predložak. Radovi Staroslavenskog instituta 5: 99-161.

ŠTEFANIĆ i sur. 1969. Vjekoslav Štefanić i suradnici (Biserka Grabar, Anica Nazor, Marija Pantelić). Hrvatska književnost srednjega vijeka, Pet stoljeća hrvatske književnosti 1. 1969. Zagreb: Zora, Matica hrvatska.

TOMASOVIĆ, Mirko. 1999. Marko Marulić Marul. Zagreb-Split: Književni krug, Zavod za znanost o književnosti Filozofskog fakulteta u Zagrebu.

VERDIANI, Carlo. 1973. O Marulićevu autorstvu Firentinskoga hrvatskoga zbornika iz XV stoljeća. Split: Čakavski sabor, Katedra za književnost i kulturu.

VERKHOLANTSEV, Julia. 2012. St. Jerome, Apostle to the Slavs, and the Roman Slavonic Rite. Speculum 87: 37-61.

VERKHOLANTSEV, Julia. 2013. St. Jerome as a Slavic Apostle in Luxemburg Bohemia. Viator 44: 251-286.

VERKHOLANTSEV, Julia. 2014. The Slavic Letters of St. Jerome. The History of the Legend and Its Legacy, or, How the Translator of the Vulgate Became an Apostle of the Slavs. DeKalb-Illinois: Northern Illinois University Press.

VERKHOLANTSEV, Julia. 2015. Croatian Monasticism and Glagolitic Tradition: Glagolitic Lettera at Home and Abroad. In Monasticism in Eastern Europe and the Former Soviet Republics, ed. Ines Angeli Murzaku, 40-61. London-New York: Routledge.

ZLATAR, Andrea. 1989. Marulićev polemički spis In eos qui beatum Hieronymum Italum esse contendunt. Dani hvarskog kazališta 15: 213-220. 


\section{The Legend of St. Jerome in Croatian Glagolitic Petris Miscellany (1468)}

Modern hagiotopographic studies confirm that the cult of St. Jerome was widely developed in Croatia and especially in Dalmatia. St. Jerome was worshipped by the Croatian Glagolitic clergy as the author and founder of the Croatian Glagolitic culture. The older Croatian literary and liturgical traditions preserve multiple and various legends about St. Jerome. Croatian texts, recorded in multiple scripts and languages, written in Glagolitic as well as in Latin characters, provide the most common motives of the Jerominian hagiography. This article aims to portray the Crotian medieval Jeronimian legends in the form of a survey. The Croatian Glagolitic Čtenie s(ve)tago Eronima Hrvatina from Petris Miscellany (1468) is published in the Latin alphabet transliteration. A close similarity with the Czech Pasional and Legenda aurea is identified.

Keywords: St. Jerome, Croatian Medieval Literature, Croatian Glagolitic Hagiography, Petris Miscellany

Ključne riječi: sveti Jeronim, hrvatska srednjovjekovna književnost, hrvatskoglagoljske hagiografije, Petrisov zbornik

Vesna Badurina Stipčević Staroslavenski institut HR-10000 Zagreb, Demetrova 11 vesna.stipcevic@stin.hr 


\section{FILOZOFSKI FAKULTET SVEUČILIŠTA U ZAGREBU \\ ZAVOD ZA HRVATSKU POVIJEST \\ INSTITUTE OF CROATIAN HISTORY \\ INSTITUT FÜR KROATISCHE GESCHICHTE}
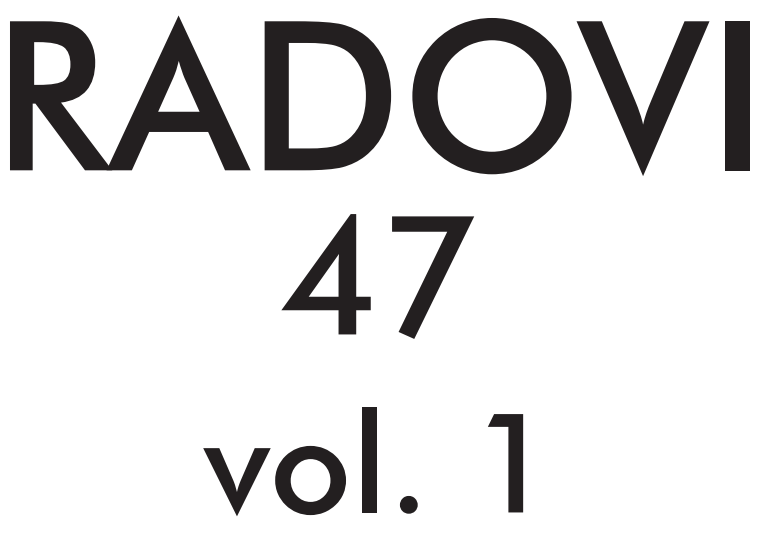

ZAVOD ZA HRVATSKU POVIJEST

FILOZOFSKOGA FAKULTETA SVEUČILIŠTA U ZAGREBU

\section{PF press \\ ZAGREB 2015.}




\title{
RADOVI ZAVODA ZA HRVATSKU POVIJEST FILOZOFSKOGA FAKULTETA SVEUČILIŠTA U ZAGREBU
}

\author{
Knjiga 47, vol. 1
}

\author{
Izdavač / Publisher \\ Zavod za hrvatsku povijest \\ Filozofskoga fakulteta Sveučilišta u Zagrebu \\ FF-press \\ Za izdavača / For Publisher \\ Vlatko Previšić \\ Glavni urednik / Editor-in-Chief \\ Hrvoje Gračanin \\ Izvršna urednica / Executive Editor \\ Inga Vilogorac Brčić \\ Uredništvo / Editorial Board
}

Bruna Kuntić-Makvić (stara povijest/ancient history), Zrinka Nikolić Jakus (srednji vijek/ medieval history), Hrvoje Petrić (rani novi vijek/early modern history), Željko Holjevac (moderna povijest/modern history), Tvrtko Jakovina (suvremena povijest/contemporary history),

Silvija Pisk (mikrohistorija i zavičajna povijest/microhistory and local history),

Zrinka Blažević (teorija i metodologija povijesti/theory and methodology of history)

Međunarodno uredničko vijeće / International Editorial Council

Denis Alimov (Sankt Peterburg), Živko Andrijašević (Nikšić), Csaba Békés (Budapest), Rajko Bratož (Ljubljana), Snježana Buzov (Columbus, Ohio), Svetlozar Eldarov (Sofija), Toni Filiposki (Skopje), Aleksandar Fotić (Beograd), Vladan Gavrilović (Novi Sad), Alojz Ivanišević (Wien),

Egidio Ivetić (Padova), Husnija Kamberović (Sarajevo), Karl Kaser (Graz),

Irina Ognyanova (Sofija), Géza Pálffy (Budapest), Ioan-Aurel Pop (Cluj),

Nade Proeva (Skopje), Alexios Savvides (Kalamata), Vlada Stanković (Beograd), Ludwig Steindorff (Kiel), Peter Štih (Ljubljana)

Izvršna urednica za tuzemnu i inozemnu razmjenu / Executive Editor for Publications Exchange Kristina Milković

Tajnik uredništva / Editorial Board Assistant

Dejan Zadro

Adresa uredništva/Editorial Board address

Zavod za hrvatsku povijest, Filozofski fakultet Zagreb, Ivana Lučića 3, HR-10 000, Zagreb

Tel. ++385 (0)1 6120 150, 6120 158, faks ++385 (0)1 6156879

Časopis izlazi jedanput godišnje / The Journal is published once a year

Časopis je u digitalnom obliku dostupan na / The Journal in digital form is accessible at Portal znanstvenih časopisa Republike Hrvatske „Hrčak“ http://hrcak.srce.hr/radovi-zhp

Financijska potpora za tisak časopisa / The Journal is published with the support by

Ministarstvo znanosti, obrazovanja i športa Republike Hrvatske

Časopis je indeksiran u sljedećim bazama / The Journal is indexed in the following databases:

Directory of Open Access Journals, EBSCO, SCOPUS, ERIH PLUS 
Naslovna stranica

Iva Mandić

Grafičko oblikovanje i računalni slog

Marko Maraković

Lektura

Samanta Paronić

Tisak

Web2tisak, Zagreb

Naklada

250 primjeraka

Časopis je u digitalnom obliku dostupan na Portalu znanstvenih časopisa Republike Hrvatske ,Hrčak“ http://hrcak.srce.hr/radovi-zhp

The Journal is accessible in digital form at the Hrcak - Portal of scientific journals of Croatia http://hrcak.srce.hr/radovi-zhp 


\section{RADOVI 47}

\section{vol. 1}

ZaVoda za hrVAtSku poviJest FILOZOFskoga fakulteta SVeuČILIŠTA u Zagrebu 


\title{
Tematski blok / Themed issue
}

\section{TREĆOREDSKA GLAGOLJAŠKA TRADICIJA U EUROPSKOM KONTEKSTU TERTIARY GLAGOLITIC TRADITION IN EUROPEAN CONTEXT}

\author{
Radovi međunarodnoga znanstvenog skupa \\ održanoga 27. i 28. IX. 2013. na Hrvatskom katoličkom sveučilištu u Zagrebu \\ u organizaciji \\ Provincije franjevaca trećoredaca glagoljaša u Zagrebu, Hrvatskoga katoličkog \\ sveučilišta u Zagrebu, Filozofskoga fakulteta Sveučilišta u Zagrebu - Odsjek za \\ povijest, Filozofskoga fakulteta Sveučilišta u Splitu - Odsjek za povijest, Instituta \\ za povijest umjetnosti u Zagrebu i Staroslavenskoga instituta u Zagrebu \\ Proceedings of the International Scientific Conference \\ held on 27th and 28th September 2013 at the Catholic University of Croatia in Zagreb \\ and organized by \\ the Province of the Glagolitic Friars of the Third Order Regular, Catholic University \\ of Croatia in Zagreb, Faculty of Humanities and Social Sciences of the University \\ of Zagreb - Department of History, Faculty of Humanities and Social Sciences of \\ the University of Split - Department of History, Institute of Art History, \\ and Old Church Slavonic Institute
}

Gosti urednici / Guest editors

\author{
Ivan BOTICA \\ Tomislav GALOVIĆ \\ Kristijan KUHAR
}

